\title{
Regional Disparities in Slovakia and The Czech Republic in the Context of Sustainable Growing of Energy Plants
}

\author{
Marián Kotrla ${ }^{1}$, Kristína Mandalová2*, Martin Prčík ${ }^{3}$
}

\begin{abstract}
The aim of the paper is to evaluate regional disparities in selected countries of Central Europe (Slovakia and the Czech Republic) in the context of sustainable growing of energy plants. Targeted growing of fast-growing energy plants can ensure increasing the share of renewable energy sources and contribute to the sustainable development of regions. Regional disparities in the possibility of biomass production of energy plants in Slovakia and the Czech Republic were evaluated according to soil and climatic factor. On average, $18.71 \%$ of the regions in Slovakia and $30.59 \%$ in the Czech Republic are less suitable for the agriculture use. These soils may be exempted from the agricultural land fund and used for non-food use. The real area of currently targeted growing of energy plants is low $(0.0265 \%$ of the area of agricultural land fund in Slovakia and $0.0643 \%$ in the Czech Republic). Analysis of selected climate indicators confirms regional differences. The length of the vegetation period, as limiting factor of biomass production is more favorable in Slovak regions. Production ability of selected energy plants was monitored on model plantation in Nitra region (SK023). Biomass production of energy grass Miscanthus (27.95 t.ha-1) and energy plant Populus (after the second three-year yield cycle 135.14 t.ha-1) confirmed economically threshold yield after the six years of growing.
\end{abstract}

Key words: sustainability; renewable energy; energy plants; regional disparities; Slovakia; The Czech Republic,

\section{Introduction}

Safety, stability and efficiency of EU's energy infrastructure are prerequisites for sustainable operation and development of the economy. In accordance with Article 3 point 1 Directive 2009/28/EC of the European Parliament and of the Council of 23 April 2009 on the promotion of the use of energy from renewable sources, member states are obliged to ensure that the share of energy from renewable energy sources in final gross energy consumption in 2020 represented its national overall target for the energy share from renewable energy sources. Renewable energy plays key role in the long-term strategy of the European Commission, as is outlined in its Energy Roadmap 2050 (COM(2011)0885). European Commission in its announcement from 2012 entitled Renewable energy: a major player in the European energy market (COM(2012)0271) has set out the areas that must intensify effort till 2020 in order to increase energy production from the EU renewable sources till 2030, as in following years and make technologies of renewable energy sources less expensive, more competitive and ultimately market oriented.

'Department of Regional Bioenergy,

2Dean's Office,

32Department of Sustainable Development, Faculty of European Studies and Regional Development, Slovak University of Agriculture in Nitra, Slovakia

* corresponding author. 
In terms of the sustainable energy enters the foreground close link between energy and climate change. Biomass area is in the context of the sustainable energetics and energy closely linked with the rural development and dynamically developing sector of bioenergy.

\section{Sustainable Development Indicator - Climate Change and Energy}

The aim of the EU Strategy for sustainable development (COM(2011)0264) is to ensure high level of environmental protection, social equity and cohesion, economic prosperity and active promotion of sustainable development worldwide. Among these key linkages exist many connections - use of renewable energy sources and climate change, climate change and poverty, poverty and use of environmentally sensitive technologies and procedures and so on.

To measure progress towards the strategy were set indicators of sustainable development. Indicators of sustainable development at European Union level are expressed in 10 basic topics that every (except last one) has defined so called main (headline) indicator, followed by several other indicators. In EU sustainable development strategy is the issue of the energy one of the priorities. In most countries are adopted energy saving policies and incentive development of technologies for renewable energy sources.

Strategy Europe $2020(\mathrm{COM}(2010) 2020)$ is a ten-year strategy in the area of employment and growth, that is divided into five basic targets. One of them is the climate change and energy sustainability. Within this target is determined the need to reduce greenhouse gas emissions by $20 \%$ compared to 1990 , increase the share of renewable energy to $20 \%$ and achieve $20 \%$ increase in energy efficiency.

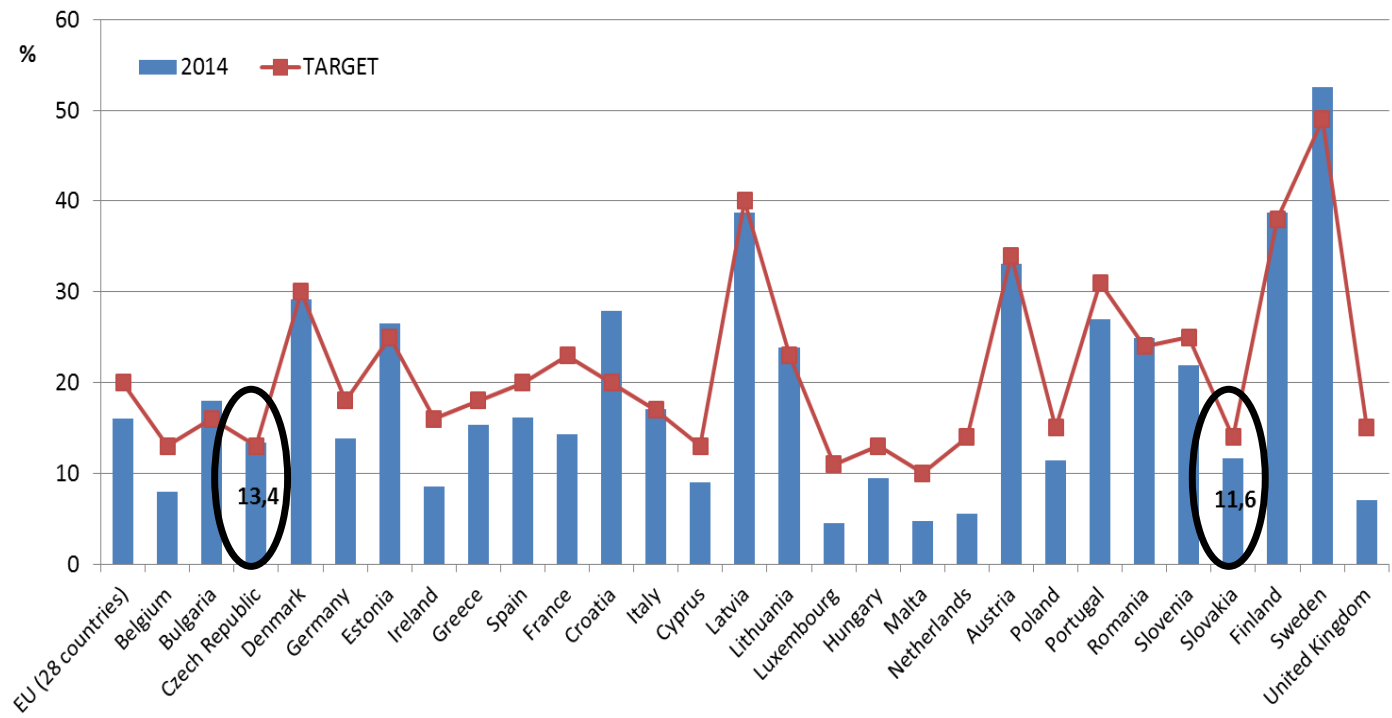

Figure 1: Share of renewable energy in gross final energy consumption (\%)

(Source: http:/ / ec.europa.eu/ eurostat/ tgm/ table.do?tab=tableEoplugin=1 \&olanguage=enespcode=t2020_31) 
The EU and most member states achieve steady progress to meet targets in 2020 - in 2014 in the context of the gross final energy consumption achieved the expected share of $15.3 \%$ (Figure 1). Due to expected trends in following years, some member states will have to intensify their effort and use cooperation mechanisms with other member states in order to make progress. Slovakia has set 14\% target and the Czech Republic 13\% target for the share of renewable energy sources by 2020 .

\section{Diversification of renewable energy sources use - biomass}

In terms of production of renewable energy sources from biomass the availability of raw materials is significant aspect (e.g. Scarlat et al., 2010), as well as conditions of the sustainability of the affected natural resources in relation to increasing effective land use and inputs, with respect to necessary capacities to ensure food production (e.g. Bringezu et al., 2009). Renewable energy from biomass grown on agricultural land is worldwide discussed and evaluated issue, complexly in the works of Clifton-Brown et al. (2011), Hill et al. (2009), Dohleman et al. (2010) and Smeets \& Faaij (2010). Lund (2007) in his analysis discussed perspective of renewable energy source in developing of sustainable development strategy.

The variety of biomass means also its territorial dispersal. Research and development in this area is oriented on closer cooperation at regional level to ensure adequate, sustainable and cost-effective supply of raw materials to biorefineries. The focus of research and development activities is highly influenced by specific conditions. These are especially soil and climatic conditions, economic priorities of individual states and structure of land ownership.

Share of biomass use is less than 1\% in Slovakia. Slovakia has developed and adopted National Renewable Energy Action Plan (Slovakia) according to Directive 2009/28/EC on the promotion of the use of energy from renewable sources. For renewable energy sources are set national targets for 2020 for the share of energy in transport, electricity, heating and cooling. The Slovakia has a duty to increase the use of renewable energy sources to $14 \%$ from gross final energy consumption in 2020 (in 2005 the value was 6.7\%). The Czech Republic increases the intensity of support of use of renewable energy sources through different activities and support in legislation. State Energy Policy of the Czech Republic is in accordance with the National Renewable Energy Action Plan of the Czech Republic and tries to ensure full use of biomass potential set in Biomass Action Plan for the period 2012 - 2020 and hold line with the requirements protecting the environment and to ensure food safety. The Czech Republic's target to increase energy share of renewable energy sources in gross final energy consumption by 2020 has met already in 2014 and therefore the government decided to increase the initial target from $13 \%$ to $15.3 \%$. The reason was a revision of expected total energy consumption in 2020 .

In Slovakia and the Czech Republic regions count with targeted use of growing so called energy plants and grasses, except waste biomass from the agricultural and forest production. The targeted growing of energy biomass ensures diversification of sustainable use of renewable energy sources at regional level.

Growing of energy plants depends on environmental factors. Lack of water, high temperatures and high insolation restricts the plant production. It is important to identify 
genotypes that are able to use specific conditions that provide different climate regions to create the greatest yield biomass.

Targeted growing of energy plants has potential of application in economic and social practice and leads to increase in sustainable rural development. Partial aim of growing energy plantations is to reduce the energy dependence of the state and its individual regions, reducing greenhouse gas emissions, increasing the share of renewables in the energy mix of the state. Energy plantations are directly related to the soil and biomass interaction in relation to sustainable use of the countryside in order to enhance overall agricultural productivity. Benefit of growing energy plants is the development of economic activities aimed at use of energy biomass, especially in rural areas with respect to biodiversity and the environment.

\section{The Aim of the Paper and the Methods Used}

Aim of the paper is to evaluate regional disparities in selected Central European countries in terms of opportunities for sustainable growing of energy plants and the opportunities for diversification of use of renewable energy sources for the evaluation of selected indicators of sustainable development.

Regional disparities in Slovakia and the Czech Republic were evaluated on the basis of the statistical territorial division - NUTS 3 (Nomenclature of Territorial Units for Statistics). These administrative units represent a geographical area with an administrative authority that is empowered to take administrative or strategic decisions in accordance with the legal and institutional framework of the Member State of the EU. NUTS 3 are territorial units characterized as small regions for specific diagnoses. Slovakia is divided into 8 regions and the Czech Republic into 14 regions (Table 1).

Table 1: Comparison of NUTS 3 regions in Slovakia and the Czech Republic

\begin{tabular}{|c|c|c|c|c|}
\hline 家 & $\begin{array}{l}\text { Code of } \\
\text { NUTS } 3\end{array}$ & Name of Region & Area in ha & Population \\
\hline \multirow{8}{*}{$\begin{array}{l}\frac{\pi}{y} \\
\frac{\pi}{\tilde{v}} \\
\frac{0}{0}\end{array}$} & SK011 & Bratislava & 633,288 & 205,250 \\
\hline & SK021 & Trnava & 559,697 & 414,660 \\
\hline & SK022 & Trenčín & 589,935 & 450,200 \\
\hline & SK023 & Nitra & 682,527 & 634,380 \\
\hline & SK031 & Žilina & 690,434 & 680,870 \\
\hline & SK032 & Banská Bystrica & 653,024 & 945,440 \\
\hline & SK041 & Prešov & 820,697 & 897,390 \\
\hline & SK042 & Košice & 796,650 & 675,450 \\
\hline \multirow{9}{*}{ 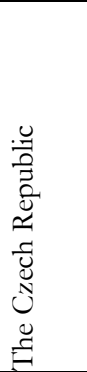 } & CZ010 & Prague & $1,267,449$ & 49,616 \\
\hline & CZ020 & Central Bohemian & $1,326,857$ & $1,101,613$ \\
\hline & CZ031 & South Bohemian & 637,834 & $1,005,798$ \\
\hline & CZ032 & Plzeň & 576,635 & 756,097 \\
\hline & CZ041 & Karlovy Vary & 297,804 & 331,429 \\
\hline & CZ042 & Ústí nad Labem & 822,850 & 533,471 \\
\hline & CZ051 & Liberec & 439,639 & 316,343 \\
\hline & CZ052 & Hradec Králové & 551,421 & 475,899 \\
\hline & CZ053 & Pardubice & 516,149 & 451,896 \\
\hline
\end{tabular}




\begin{tabular}{|l|l|l|l|l|}
\hline $\mathbf{C Z 0 6 3}$ & Vysočina & 509,475 & 679,559 \\
\cline { 2 - 5 } & CZ064 & South Moravian & $1,175,023$ & 719,506 \\
\cline { 2 - 5 } & CZ071 & Olomouc & 634,720 & 526,690 \\
\cline { 2 - 5 } & CZ072 & Zlín & 584,676 & 396,292 \\
\cline { 2 - 5 } & CZ080 & Moravian-Silesian & $1,213,311$ & 542,763 \\
\hline
\end{tabular}

(Source: Statistical Office of the Slovak Republic and Czech Statistical Office (2017), Own Processing)

Regional disparities in the possibility of biomass production of energy plants in Slovakia and the Czech Republic were evaluated according to soil and climatic factor. Soil factor was expressed as the area of agricultural land suitable for growing of fast-growing plants. The data were processed according to the database of National Agriculture and Food Centre in Slovakia and database of The Research Institute for Soil and Water Conservation in the Czech Republic. Areas of registered areas of fast-growing plants grown on agricultural land are processed according to database of Slovak regions and database eAgri.cz in the Czech Republic. Selected climatic factors - the average monthly air temperatures and average precipitations for the whole vegetation period (April to October) in various regions were processed according to database of Slovak Hydrometeorological Institute and Czech Hydrometeorological Institute for the years 2010 to 2015.

\section{Model plantations of energy plants in Nitra region - Slovakia}

Model area of experimental research of growing of fast-growing plants on agricultural land is located in Nitra region (Slovakia) in cadastre of village Kolínany. GPS

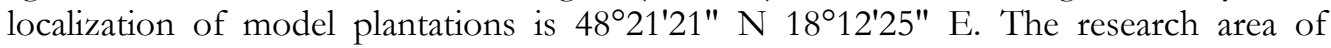
energy plants was established on the Farm holding of Slovak university of agriculture in village Kolínany (plantation of energy plant Populus) and 2010 (plantation of energy grass Miscanthus). The model area is situated in a very warm to hot, very dry lowland climate region. A more detailed description of abiotic conditions of model area is stated in the work of Prčík \& Kotrla (2016). Climate overview of model area is shown in Figure 2.

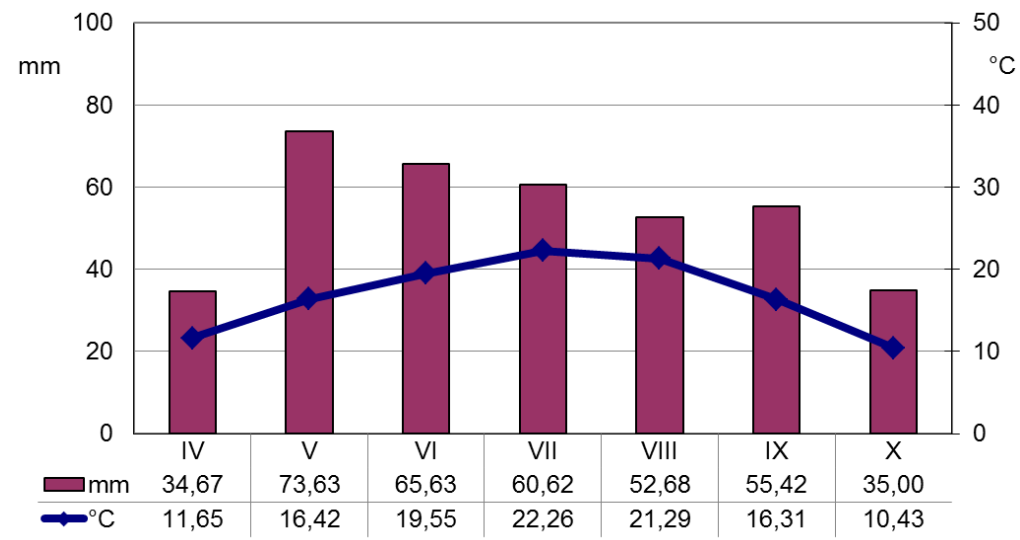

Figure 2: Selected climate indicators evaluated for vegetation period in 2010 2015 on model plantation in Nitra region (Slovakia) (Source: Slovak Hydrometeorological Institute, Own Processing) 
Production potential of fast-growing energy plants was evaluated on two selected species of plants - energy grass genus Miscanthus and energy plant genus Populus. The difference between the investigated genotypes Miscanthus (Miscanthus sinensis Tatai and Miscantus $\times$ giganteus (Greef et Deuter, 1993)) was in the planting material (rhizomes and in vitro seedlings). A more detailed description of genotypes is stated in Jureková et al. (2012) and Prčík \& Kotrla (2013). The genus Populus (poplar) represented four Italian varieties: Monviso, Pegaso, AF- 2 and Sirio. With the characteristic of individual varieties deals Demo et al. (2013) in his work.

A comparison of both types of energy plants in specific regional conditions was evaluated through number of produced above-ground biomass of individuals converted to produce yield in t.ha- ${ }^{-1}$. Taking of above-ground phytomass of energy grass Miscanthus was done in March of following year always after each vegetation year. Yield of poplar varieties was evaluated at the end of first (2012) and second (2015) three-year growing cycle. Fresh weight of dry biomass was monitored at harvested humidity. The collected biomass of model individuals was dried in an oven at temperature $105^{\circ} \mathrm{C}$. Differences in monitored indicators of production potential of genus in vegetation years were analysed by one-way analysis of variance (ANOVA), processed in a statistical package STATISTICA 12.

\section{Results and Discussion}

Possibilities of targeted growing of energy plants are regionally contingent. The important factors are abiotic factors of the environment, mainly climatic conditions. Soil indicator is an important indicator in relation to the spatial localization of these energy plantations. Each country must use agricultural land fund to ensure their food security. Areas of soils that are less inferior, marginal, contaminated and are not used for the purpose of growing field crops can also be used for growing non-food plants. One of the possibilities of its use is also growing fast-growing plants and grasses. A similar analysis of suitable habitats in regions of Germany for growing fast-growing plants also carried out in Germany (Schorling et al., 2015). The authors focused on the spatial localization of energy grass Miscanthus based on soil and climatic parameters. 
a)

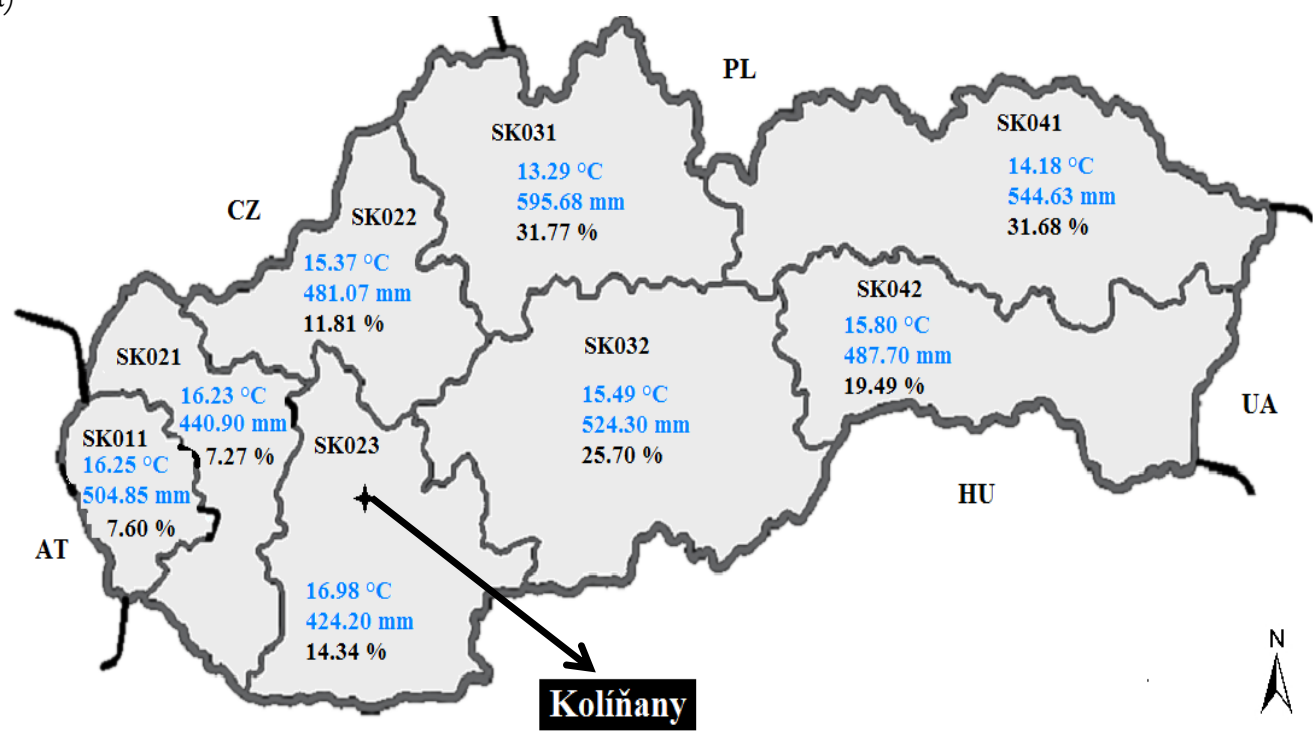

b)

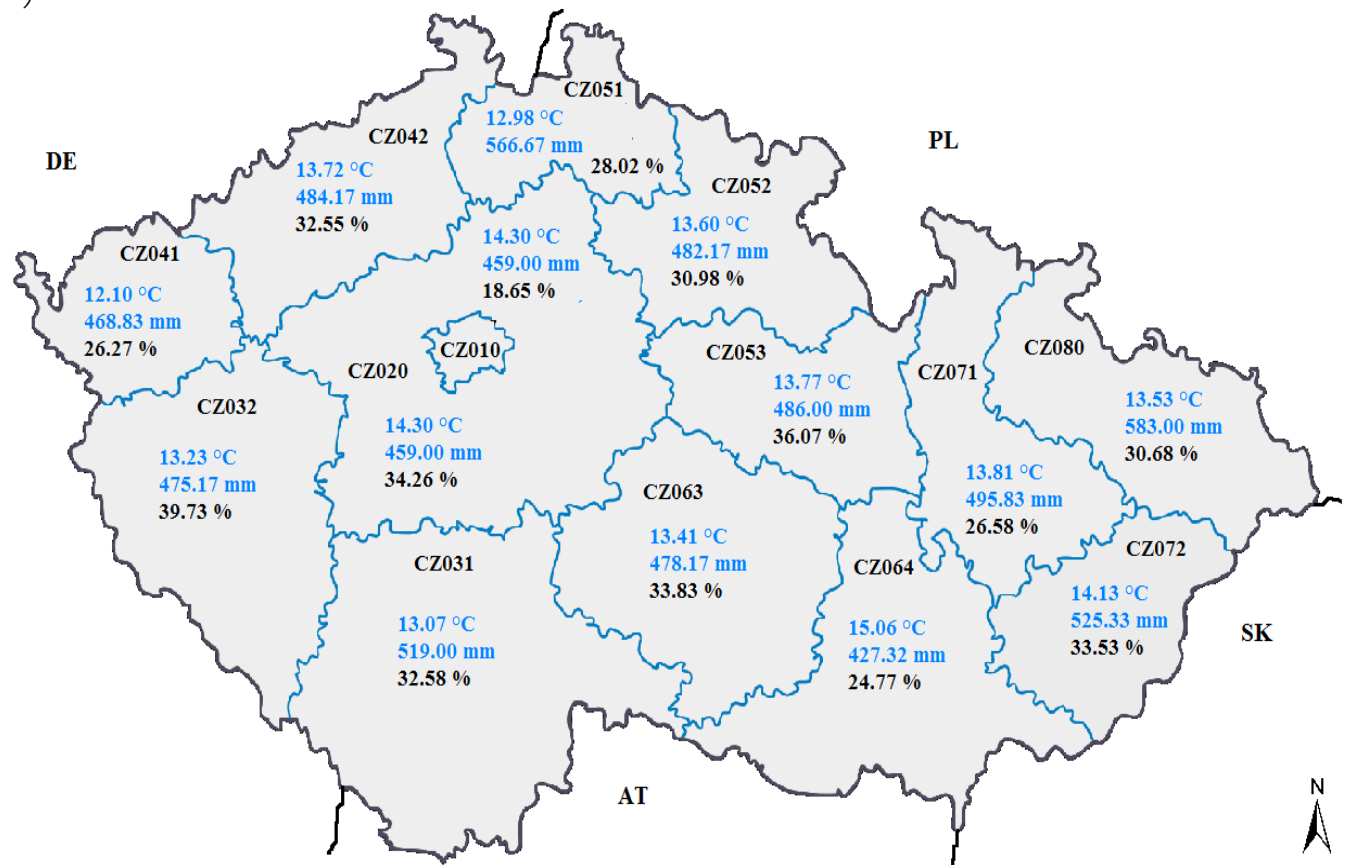

Figure 3: Spatial definition of Slovak regions (a) and the Czech Republic regions (b) - selected climate indicators: average air temperature and average precipitation for the whole vegetation period (April - October) and \% area representation of agricultural land suitable for the growing of fast-growing plants (Source: Own processing) 
As reported Vilček (2011), Slovakia needs to have a minimum agricultural land area of 1.367.853 ha that represents about $56 \%$ to food self-sufficiency of currently registered agricultural land of Slovakia. These soils of high quality can be used for growing food plants. It is a primary agricultural land. $46 \%$ of agricultural land consists of soil that can be used for the growing of energy plants. In the Czech Republic in ensuring 100\% food self-sufficiency is possible to use $31 \%$ of agricultural land for the renewable energy sources (680.000 ha of arable land and 440.000 ha of permanent grasslands). Those are soils of inferior quality, especially soils of $3 \mathrm{rd}, 4$ th and 5 th grade protection. On the analysis of land fund in Slovak regions and the Czech Republic regions were prepared spatial differentiation of $\%$ representation of possible area of agricultural land from the total area of the region for energy use (Figure 3).

Table 2: Regional disparities in the land area suitable for growing and areas of actually grown energy plants and \% expression of area of the total area of the region

\begin{tabular}{|c|c|c|c|c|c|}
\hline 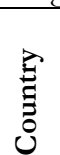 & Code of NUTS 3 & $\begin{array}{l}\text { The area of land } \\
\text { suitable for growing } \\
\text { FGP (ha) }\end{array}$ & $\begin{array}{l}\% \text { of the } \\
\text { total area } \\
\text { of the } \\
\text { region }\end{array}$ & $\begin{array}{l}\text { Land area used for } \\
\text { growing FGP (ha) }\end{array}$ & $\begin{array}{l}\% \text { of the } \\
\text { total area } \\
\text { of the } \\
\text { region }\end{array}$ \\
\hline \multirow{8}{*}{$\begin{array}{l}\frac{\pi}{\pi} \\
\frac{a}{n} \\
\frac{0}{\omega}\end{array}$} & SK011 & 15,596 & 7.60 & 147.59 & 0.0719 \\
\hline & SK021 & 30,149 & 7.27 & 54.25 & 0.0131 \\
\hline & SK022 & 53,157 & 11.81 & 0 & 0 \\
\hline & SK023 & 90,971 & 14.34 & 28.89 & 0.0046 \\
\hline & SK031 & 216,293 & 31.77 & 20.36 & 0.0030 \\
\hline & SK032 & 243,004 & 25.70 & 93.29 & 0.0099 \\
\hline & SK041 & 284,318 & 31.68 & 4.01 & 0.0004 \\
\hline & SK042 & 131,639 & 19.49 & 3.31 & 0.0005 \\
\hline \multirow{14}{*}{ 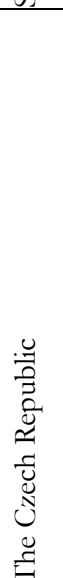 } & CZ010 & 9,253 & 18.65 & 0 & 0 \\
\hline & CZ020 & 377,388 & 34.26 & 211.33 & 0.0192 \\
\hline & CZ031 & 327,657 & 32.58 & 215.08 & 0.0214 \\
\hline & CZ032 & 300,365 & 39.73 & 832.26 & 0.1101 \\
\hline & CZ041 & 87,083 & 26.27 & 45.36 & 0.0137 \\
\hline & CZ042 & 173,628 & 32.55 & 202.83 & 0.0380 \\
\hline & CZ051 & 88,642 & 28.02 & 103.46 & 0.0327 \\
\hline & CZ052 & 147,429 & 30.98 & 199.97 & 0.0420 \\
\hline & CZ053 & 162,996 & 36.07 & 153.06 & 0.0339 \\
\hline & CZ063 & 229,920 & 33.83 & 269.73 & 0.0397 \\
\hline & CZ064 & 178,190 & 24.77 & 192.78 & 0.0268 \\
\hline & CZ071 & 139,981 & 26.58 & 165.05 & 0.0313 \\
\hline & CZ072 & 132,157 & 33.35 & 77.01 & 0.0194 \\
\hline & CZ080 & 166,525 & 30.68 & 221.24 & 0.0408 \\
\hline
\end{tabular}

(Source: Own processing)

In comparison of regions related to the soil factor is the area of soil suitable for energy use differentiated (Table 2). Assumption for higher areas of agricultural lands, located at soils less suitable for the field crops, is in northern Slovak regions and in regions where is greater segmentation relief (Žilina Region - SK031 - 216.293 ha; Prešov Region - SK41 - 284.318 ha and Banská Bystrica Region - SK32 - 243.004 ha). In the Czech Republic 
is the area for the growing of energy plants divided evenly in all regions. In the Czech Republic regions have more evenly divided segmentation relief. On average $30.59 \%$ area of the regions forms area of $3 \mathrm{rd}$, 4th and 5 th grade soil protection according to Soil Ecological Units. According to Czech legislation that soils can be excluded from agricultural land fund and used for non-food use.

Currently, in fulfilling indicator of sustainable development for climate and energy area is share of use of renewable energy sources from the targeted growing plantations of energy plants in monitored regions extremely low. In Slovakia is a real area where are growing energy plants $0.0265 \%$ of the area of agricultural land fund $(0.0129 \%$ of the total area of the country). Share in the Czech Republic regions is $0.0643 \%$ of the area of agricultural land fund $(0.0335 \%$ of the total area of the country). A more detailed analysis of the land area suitable for actual use and growing of fast-growing plants for regions are stated in Table 2.

Fast-growing plants Populus and Miscanthus for their growth and production of sufficient quantities of biomass need a suitable temperature and humidity conditions during the vegetation period. On the basis of analysis of average monthly air temperatures and monthly average precipitations were processed regional differences in selected climatic parameters (Figure 4).

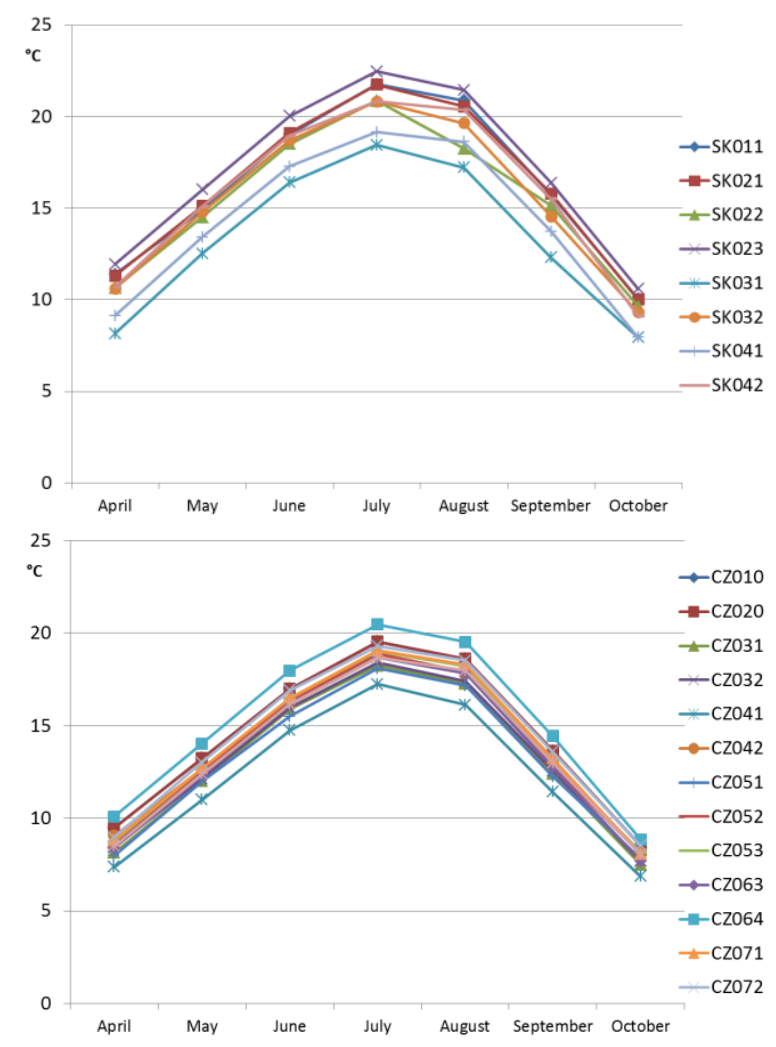




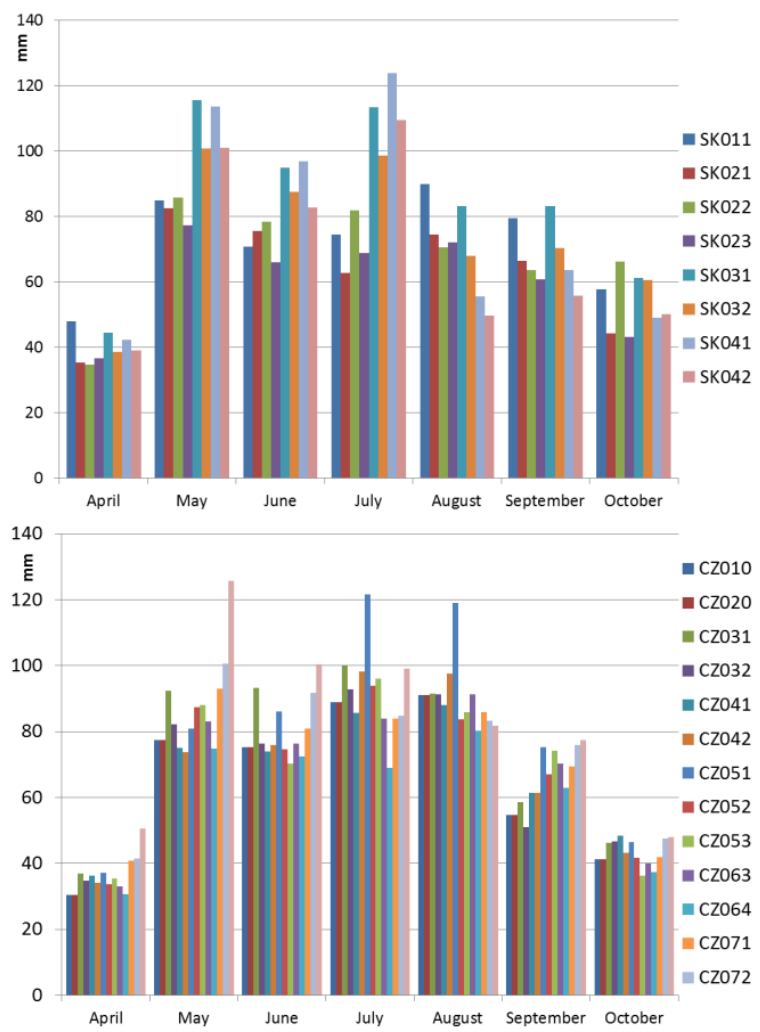

Figure 4 Regional disparities of selected climate indicators - average monthly air temperatures and average monthly precipitations during vegetation period (April-October)

(Source: Slovak. Hydrometeorological Institute and Czech Hydrometeorological Institute, Own Processing)

Graph (Figure 4) of average monthly air temperatures during vegetation period shows regional differences when compared within countries, but also differences between the Czech Republic and Slovak regions. Temperature conditions for growth and aboveground biomass energy plant organs are more favorable in Slovak regions. Limiting climatic factor to activate the plant growth is the beginning of the vegetation period and its length. A similar spatial differentiation of regions suitable for growing energy grass Miscanthus based on climatic parameters solved Xue et al. (2016) in China. Limited factor in evaluation of climatic conditions was length of vegetation period defined as the period of growth of the biomass with beginning at average daily temperature $\geq 10{ }^{\circ} \mathrm{C}$ and precipitation during the vegetation period $\geq 400 \mathrm{~mm}$. In Slovak regions (expect SK031 and SK041 region) reach average air temperature above $10{ }^{\circ} \mathrm{C}$ already in mid-April. It is a beginning of activation of growth. In the Czech Republic that temperature reach only region CZ064 (South Moravian Region). To this value by the temperature approach regions CZ010, CZ020 a CZ042. Precipitation activity during vegetation period is comparable in regions. For the production of sufficient quantities of biomass need energy plants Populus a Miscanthus except favorable temperature conditions also enough humidity during vegetation period (precipitation $\geq 400 \mathrm{~mm}$ ). On the basis of monthly 
precipitation analysis (Figure 4) in the last six years there has been a significant deficit of precipitations during the vegetation period.

More complex view on regional disparities in relation to climatic parameters expressed Figure 3. In the various regions is spatially expressed average air temperature and precipitation during whole vegetation period (April to October) in the last six years. The Slovak regions are climatically most acceptable regions situated in the south and southeast regions. Conversely northern regions (SK031 and SK041) are in terms of climatic factors less appropriate - shorter growing season and high precipitation. There are also local exceptions in relation to the altitude of the specific habitat. In Czech regions are for growing energy plants, in view of climate indicators, the most suitable regions of Central Bohemian and Moravian (CZ010, CZ020, CZ064 and CZ072).

\section{Yield potential of fast-growing energy plants in model Nitra region in Slovakia}

Plants Miscanthus and Populus localized on model area of Nitra region were in terms of biomass production monitored in years 2010-2015 (Table 3). The highest increases in the biomass production were (both Miscanthus genotypes) in third vegetation year (year 2012), when reached $\varnothing$ production 24.85 t.ha-1, which compared to 2011 increased by almost $40 \%$. Following years was biomass increase in comparison to last vegetation period lower ( $9 \%$ in 2013,4\% in 2014). After the sixth vegetation year (2015) reach crop $\varnothing$ production 27.95 t.ha ${ }^{-1}$ of dry biomass. Produced biomass decreased by $3 \%$ compared to 2014. In the fifth vegetation year from established of plantation (2014) occurred culmination formation of above-ground biomass (Figure 5).

Table 3: Production of dry above-ground biomass plantations of the energy plant species ( $t$ ha ${ }^{1}$.year ${ }^{-1}$ ) grown in the research site in Kolínany, Nitra Region in Slovakia

\begin{tabular}{|l|l|l|l|l|l|l|}
\hline Energy plants / Year & $\mathbf{2 0 1 0}$ & $\mathbf{2 0 1 1}$ & $\mathbf{2 0 1 2}$ & $\mathbf{2 0 1 3}$ & $\mathbf{2 0 1 4}$ & $\mathbf{2 0 1 5}$ \\
\hline Miscantus $\times$ giganteus & 11.10 & 18.10 & 27.10 & 30.30 & 30.90 & 30.1 \\
\hline Miscanthus sinensis Tatai & & & & & & \\
& 10.80 & 16.90 & 22.60 & 24.10 & 26.30 & 25.8 \\
\hline \hline Miscanthus - average & $\mathbf{1 0 . 9 5}$ & $\mathbf{1 7 . 5 0}$ & $\mathbf{2 4 . 8 5}$ & $\mathbf{2 7 . 2 0}$ & $\mathbf{2 8 . 6 0}$ & $\mathbf{2 7 . 9 5}$ \\
\hline \hline Populus MONVISO & & 28.80 & 58.33 & 21.92 & 19.86 & 89.7 \\
\hline Populus PEGASO & & 18.59 & 58.31 & 14.09 & 42.80 & 67.13 \\
\hline Populus AF-2 & & 26.69 & 40.73 & 12.34 & 43.66 & 197.84 \\
\hline Populus SIRIO & & 30.11 & 48.53 & 15.51 & 31.60 & 185.87 \\
\hline \hline Populus - average & & $\mathbf{2 6 . 0 5}$ & $\mathbf{5 1 . 4 7}$ & $\mathbf{1 5 . 9 7}$ & $\mathbf{3 4 . 4 8}$ & $\mathbf{1 3 5 . 1 4}$ \\
\hline
\end{tabular}

(Source: Own processing)

Biomass production of monitored Italian varieties of poplar converted to t.ha- ${ }^{-1}$.year ${ }^{-1}$ of dry matter is presented in Table 3. Fast-growing poplars of Italian provenance in first three-year growing cycle in 2012 produced in average 51.47 t.ha $^{-1}$ of biomass. At the end of the second three-year growing cycle produced poplar yield from 67.13 t.ha $^{-1}$ to 197.84 t.ha ${ }^{-1}$ (in average 135.14 t.ha $^{-1}$ of biomass) (Figure 5). When comparing biomass production during first and second growing cycle, there were differences in biomass production. Variety Monviso increased production of dry biomass by $2.95 \%$. Variety Pegaso vice-versa, decreased total biomass in second growing cycle by $12.7 \%$. The 
varieties AF-2 and Sirio recorded a significant increase of production in comparison to the first growing cycle (AF-2 increase by $193.4 \%$ and Sirio increase by $136.4 \%$ ). On the basis of evaluation of production the aerial organs of monitored varieties of poplars are more productive plantations of varieties AF-2 and Sirio. Differences in biomass production of varieties Monviso and Pegaso with varieties AF-2 and Sirio can be caused by particular reaction of variety on cut. Varieties AF-2 and Sirio responded on the cut (in liquidation of crop at the end of the first vegetation period) positive, as evidenced by the results of the analysis of selected growth indicators.

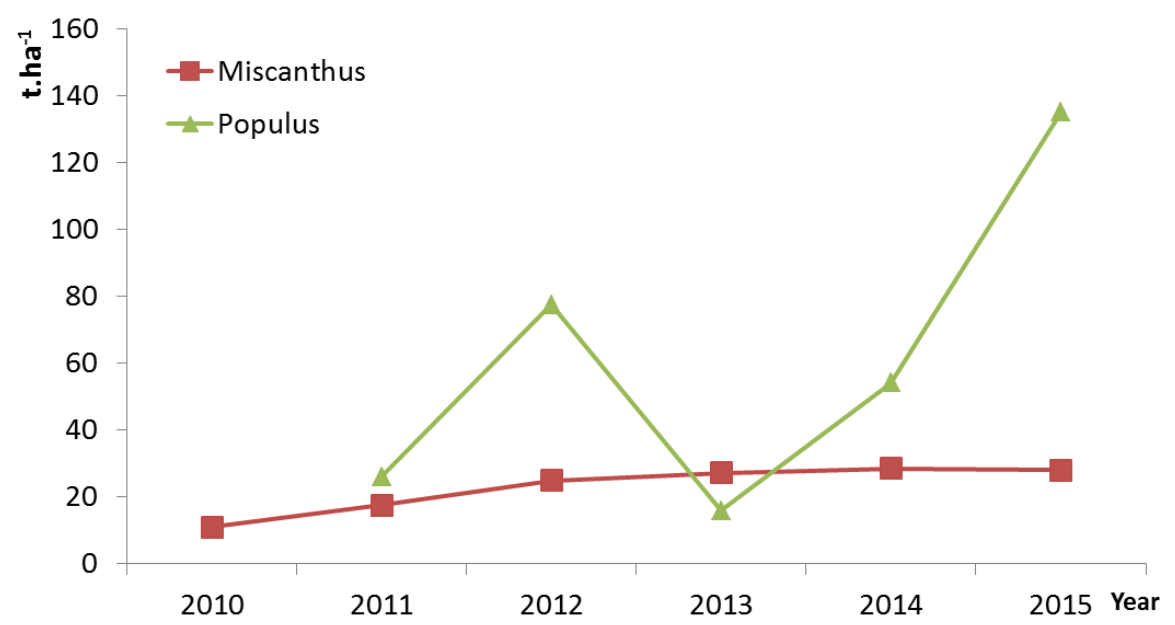

Figure 5: Dynamics of production growth of monitored energy plants on model plantation in Nitra region Slovakia (Source: Own processing)

Table 4: Single-factor analysis of variance of the biomass production between energy plants and in each experimental year (2010-2015)

\begin{tabular}{|l|l|l|l|l|}
\hline Analysed parameter & F & P-value & F critical & Significance \\
\hline Miscanthus genotypes and Years & 12.12266 & 0.004318 & 4.387374 & ++ \\
\hline Populus varieties and Years & 9.901757 & 0.000398 & 3.055568 & +++ \\
\hline
\end{tabular}

Level of significance is defined as: $\mathrm{n}$ : non-significant impact, + : significant impact in $\mathrm{P} \leq 0.05,++: \mathrm{P} \leq 0.01$ and $+++: \mathrm{P} \leq 0.001$ (Source: Own processing)

Differences in biomass production of individual genotypes Miscanthus in vegetation years 2010 to 2015 and varieties Populus are statistically highly significant (Table 4).

In the regions of southern Europe achieves above-ground dry biomass of Miscanthus yields approximately 25-30 t.ha-1 under optimal conditions (Angelini et al., 2009). CliftonBrown et al. (2011) confirmed the high biomass production in irrigated conditions in the regions of Portugal (36 t.ha-1). Larsen et al. (2015) identified regional differences in the production of Miscanthus in Denmark. Dželetović et al. (2014) indicate Miscanthus biomass yield in the range of 15.5-37.5 t.ha ${ }^{-1}$ depending on soil type (two different soil and climatic locations). Xue et al. (2016) on the basis of territory regionalization in 
China, depending on type of soil and climate environment found out Miscanthus yields on marginal areas in the range of $2.1-32.4$ t.ha $^{-1}$.

\section{Conclusion}

High interest in renewable energy sources is not only due to limited supplies of traditional energy resources. Burning fossil fuels leads to serious environmental damage. The concept of sustainable development is focused on increase and mainly protection of environment quality. Renewable energy sources are one of the ways that is possible to deal with the sustainability of the regions while ensuring sufficient energy. One of the objectives of the EU strategy for sustainable development is to increase share of use of renewable energy sources. The target is $20 \%$ by 2020 and then gradually increasing of this share. In Central European countries - Slovakia and the Czech Republic - the share is currently $11.6 \%$ to $13.4 \%$ of use of renewable energy sources. Target for both countries is to increase this share to 14\% (Slovakia) and 13\% (Czech Republic). The Czech Republic has met its target already in 2014 and therefore the government decided to increase the initial target to $15.3 \%$ by 2020 .

Biomass area is in context of sustainable energetics and energy closely linked with rural development and dynamically developing sector of bioenergy. Biomass potential as an alternative energy source is extremely high. The amount of energy stored in the biomass is up to 7.5 times higher than worldwide energy consumption. Targeted growing of fastgrowing plants can provide a higher share of renewable energy sources and contribute to the sustainable development at the regional level.

Regional disparities in the possibility of producing biomass energy plants in Slovakia and the Czech Republic were evaluated according to the soil and climatic factors. On average $18.71 \%$ of region area in Slovakia and $30.59 \%$ of region area in the Czech Republic for agricultural use is less suitable (soils of lower quality, marginal land, contaminated land and unused land). The real area of currently targeted growing of energy plants is low. In Slovakia is this share $0.0265 \%$ of the area of agricultural land fund and in the Czech Republic 0.0643\% (Slovakia - 0.0129\% and The Czech Republic $-0.0335 \%$ of the area of the country). Comparison of regions on the basis of selected climatic parameters highlighted regional differences. Temperature conditions for growth and biomass production of above-ground organs of energy plants are more favorable in Slovak regions. Limiting climatic factor to activate the plant growth is the beginning of the vegetation period and its length. In Slovak regions are climatically most suitable regions located in the southern and south-eastern regions. In Czech regions are for growing energy plants, in view of climate indicators, the most suitable regions of Central Bohemian and Moravian.

Production ability of energy plants Miscanthus and Populus was monitored on a model plantation in Nitra region (Slovakia - region SK023). After the sixth vegetation year (2015) reach energy plant Miscanthus $\varnothing$ yield 27.95 t.ha-1 of dry biomass. At the end of the second three-year growing cycle created poplars yield in an average of 135.14 t.ha $^{-1}$. Both energy plants confirmed economically threshold yield after the six years of growing.

On the basis of comparison of regions it can be observed great potential in growing energy plants. Soil and climatic factor is favorable in concerned regions. It allows the 
establishment of plantations of such plants. This kind of targeted growing may be considered for conventional growing with redirecting production to the direct energy consumption. Areas of energy plantations in evaluated regions will depend also on local requirements. Except ensuring alternative for traditional energy sources have plantations of energy plants also ecological, environmental and socio-economic benefit.

\section{Acknowledgement}

This work was supported by the Grand Agency of SUA in Nitra under the contract No. 11-GA SPU-16 and by the AgroBioTech ITMS 26220220180.

\section{References}

Angelini, L. G., Ceccarini, L., o Di Nasso, N. N. \& Bonari, E. (2009). Comparison of Arundo donax L. and Miscanthus $\times$ giganteus in a long-term field experiment in Central Italy: analysis of productive characteristics and energy balance. Biomass and bioenergy, 33(4), 635-643.

Biomass Action Plan for the period 2012 - 2020. (n.d.). Retrieved March 14, 2017, from http://eagri.cz/public/web/file/179051/APB_final_web.pdf [In Czech]

Clifton-Brown, J.C.,I., Lewandowski, B., Andersson, G., Basch, D.G., Christian, J.B., Kjeldsen, U., Jørgensen, J.V., Mortensen, A.B., Riche, K., Schwarz, K. \& Tayebi, K. (2001). Performance of 15 genotypes at five sites in Europe. Agronomy Journal, 93(5), 1013-1019.

COM(2011)0264 A Sustainable Europe for a Better World: A European Union Strategy for Sustainable Development

COM(2010)2020 EUROPE 2020 A strategy for smart, sustainable and inclusive growth

COM(2011)0885 Energy Roadmap 2050

COM(2012)0271 Renewable Energy: a major player in the European energy market

Demo, M., Prčík, M., Tóthová, D. \& Húska, D. (2013). Production and energy potential of different hybrids of poplar in the soil and climatic conditions of south-western Slovakia. Wood Research, 58(3), 439-450.

DIRECTIVE 2009/28/EC (THE RENEWABLE ENERGY DIRECTIVE). Available at http://eurlex.europa.eu/legal-content/EN/ALL/?uri=CELEX:32009L0028.

Dohleman, F. G., Heaton, E. A. \& Long, S. P. (2010). Perennial grasses as second-generation sustainable feedstocks without conflict with food production. In Handbook of Bioenergy Economics and Policy (pp. 27-37). Springer New York.

Dželetović, Ž., Maksimović, J. \& Živanović, I. (2014). Yield of Miscanthus $\times$ giganteus during crop establishment at two locations in Serbia. Journal on Processing and Energy in Agriculture, 18(2), 62-64.

Greef, J. M. \& Deuter, M. (1993). Syntaxonomy of Miscanthus $\times$ giganteus GREEF et DEU. Angewandte Botanik, 67(3-4), 87-90.

Hill, J., Polasky, S., Nelson, E., Tilman, D., Huo, H., Ludwig, L., Neumann, J., Zheng, H. \& Bonta, D. (2009). Climate change and health costs of air emissions from biofuels and gasoline. Proceedings of the National Academy of Sciences, 106(6), 2077-2082.

Huttmanová, E. (2016). Sustainable Development and Sustainability Management in the European Union Countries. European Journal of Sustainable Development, 5(4), 475-482.

Jureková, Z., Kotrla, M., Pauková, Ž. \& Prčík, M. (2012). The growth and yield of different Miscanthus genotypes in the conditions of south-western Slovakia. Acta Regionalia et Environmentalica, 9(2), $29-34$.

Larsen, S., Jaiswal, D., Bentsen, N. S., Wang, D. \& Long, S. P. (2015). Comparing predicted yield and yield stability of willow and Miscanthus across Denmark. GCB Bioenergy.

Lund, H. (2007). Renewable energy strategies for sustainable development. Energy, 32(6), 912-919.

National Renewable Energy Action Plan of the Czech Republic. (n.d.). Retrieved March 14, 2017, from http://ec.europa.eu/energy/en/topics/renewable-energy/national-action-plans 
National Renewable Energy Action Plan (Slovakia). (n.d.). Retrieved March 14, 2017, from http://ec.europa.eu/energy/en/topics/renewable-energy/national-action-plans

Prčík, M. \& Kotrla, M. (2013). Evaluation of dry matter production of Miscanthus sinensis (tatai) in the conditions of south-western Slovakia. Acta regionalia et environmentalica, 10(2), 55-58.

Prčík, M. \& Kotrla, M. (2016). Different planting material for establishment of the Miscanthus energy grass plantation. Journal of Central European Agriculture, 17(3), 778-792.

Schorling, M., Enders, C. \& Voigt, C. A. (2015). Assessing the cultivation potential of the energy crop Miscanthus $\times$ giganteus for Germany. Gcb Bioenergy, 7(4), 763-773.

Smeets, E. M. \& Faaij, A. P. (2010). The impact of sustainability criteria on the costs and potentials of bioenergy production-Applied for case studies in Brazil and Ukraine. Biomass and Bioenergy, 34(3), 319-333.

Vilček, J. (2011). Potential and quality parameters of farmland in Slovakia. Geographical Journal, 63(2), 133 154.

Xue, S., Lewandowski, I., Wang, X. \& Yi, Z. (2016). Assessment of the production potentials of Miscanthus on marginal land in China. Renewable and Sustainable Energy Reviews, 54, 932-943. 